\title{
EFFECTS OF INTELLECTUAL CAPITAL ON WOMEN MANAGERS' CAREER DEVELOPEMENT IN SELECTED DEPOSIT MONEY BANKS IN SOUTH-EAST, NIGERIA
}

\begin{abstract}
The study sought todetermine the effects of Intellectual Capital on Women Managers' Career Development in Selected Deposit Money Banks in South-East, Nigeria. The specific objective was to ascertain the effect of proficiency on career management of women managers in selected deposit money banks. The study had a population size of 4,624, out of which a sample size of 531 was used, using Bill Godden's formula at 5\% error tolerance. Instrument used for data collection was primarily questionnaire and interview. Out of 531 copies of the questionnaire that were distributed, 509 were returned while 22 were not returned. The survey research design was adopted for the study. The hypothesis was tested using Pearson product moment correlation and simple linear regression statistical tools. The findings indicated that proficiency significantly promoted career management of women managers in selecteddeposit money banks $(\mathrm{r}=0.763 ; \mathrm{t}=12.338 ; \mathrm{F}=152.224 ; \mathrm{P}<0.05)$. The study recommended that organizations should constantly send their women managers on training/developmental programmes in order to increase organizational productivity.

Keywords:Intellectual Capital, Women Managers' Career Development
\end{abstract}

\section{Introduction}

Intellectual Capacity (IC) as a term has gained much attention in research and practical business due to the rise of the new "knowledge" economy which is reflected in the displacement of the mass production based economy by an economy based on information and knowledge (Rastogi, 2000). Whereas the recognition that people are valuable and of high importance to organisations is not new and traces back to 17th century when William Petty argued that the reasons for the wealth of a company lie in the values of workers. Stewart (1997) popularised for the use of the term intellectual capital. His broad definition considered IC as "the sum of knowledge, information, intellectual property and experience held by everybody in a company, put to use to create a competitive edge and, ergo, wealth" (Stewart, 1997; Carson, Ranzija, Winefield and Massden (2004).

According to Marr (2004), intellectual capital most significantly contributes to an improved competitiveposition of an organization. Furthermore intellectual capital enables the 
organization to add value to important status thus leads to improve its competitive advantage. Organizations have identified that they require IC assets in order to comprise sustainable competitive advantages and be able to create value in a long-term basis (Johanson, Mårtensson, and Skoog, 2001)

Intellectual capital management (ICM) is defined as the direction of the value-driven transformation of human and relational capital into the structural capital of the organization (Lynn, 1998). Corporate processes (e.g., recruitment, training and compensation) help foster creativity and innovation. Together with appropriate technology and structural capital they create and share organizational knowledge which, when exploited and applied to external knowledge and relational capital, produces corporate competitive advantage.

A company's Intellectual Capital (IC) is a fundamental determinant of its success in a knowledge-based and increasingly more competitive economy. Intellectual capital is the combination of knowledge-based assets and intangible assets of a company which include its patents, brand names, employee's skills, trade secret technologies and information about consumers and supplies that havebeen utilisedto create wealth by producing a higher value asset (Stewart, 1997). Two and half decades ago, the importance of intellectual capital had increased tremendously, specifically in the developed countries. Organisations have identified that they require IC assets to comprise sustainable competitive advantages and be able to create value on a long-term basis (Johanson, Martensson, and Skoog, 2001). All of these in comparison to other three capitals, this capital, has scholars who agree that intellectual capital is an aspect of direct effect on realization of a company's value, and it has knowledge that creates competitive advantage and represents intangible value of an organization(Chin, Chen ., Ju Cheng and Hwang, 2005)

This is because the world at large has experienced a drastic change in the form of emerging wealthy business and nations (Arenas and Lavanderos, 2008). Sarmadi, (2013) has it that both companies and governments shifted their focuses from tangible assets to intellectual capital (IC) as differentiators for the sustainable competitive advantage of businesses and nations. The reason for a paradigm shift is that IC assets contribute to shareholder value more thantangible assets. And as such companies must cope with the shift and take full advantage of IC resources to improve their performance and competitive advantage (Carrell, 2007). Of course, scholars have favoured this contention by asserting that intellectual capital has become one of the primary sources of competitive advantage for companies (Bontis 1998 and Edvinson, 1997). Johannessen, Olsen and Olaisen (2005) argued that intellectual capital is meant to deal with the increased turbulence, knowledge requirements and changing requirements in an organisation,

The value organisations obtain from their intellectual capital is the result of a well-reasoned, well-planed and well-executed set of management initiatives (Harrison and Sullivan, 2002). They also argue that organisationsdesign initiatives to ensure that specific forms of value deemed important to the organisations' business strategy and routinely extracted from organisations' intellectual capital. This means that the value of an organisation's intellectual capital depends on the type of outcome desired and the organisation's context. The company's value is more than the tangible assets, the source of its value and wealth is no longer the production of material goods but the creation and manipulation of its intangible assets (Goldfinger,1997). Sullivan, (2000) opined that its ability to systematically leverage it and convert those assets into revenues. 
The messy practices and complex challenges of the current business environment have left it unpredictable. Many organisations believe that embarking into the knowledge economy is one of the best business strategies to making sure for the organisation to survive in the very competitive and turbulent environment. As a way of improving their immediate and longterm business performance, companies have recently given focus on knowledge and intellectual capital by managing and leveraging their intellectual capital. All organisations storeintellectual capital as the knowledge it possesses, this may be tacit knowledge, personal knowledge possessed by an employee and may be explicit knowledge, codified and stored by the organisation and available to individuals throughout the structure (Nonaka and Takeuchi, 1995).

Intellectual capital is a key resource that aids in driving Organisational Performance and value creation (Mayo, 2000).Measuring performance is something that all organisations do (Parker, 2000). B.W. Associates (1994) define performance as the manner or quality of functioning, which implies that management of performance is concerned with the manner or quality of managing and Kaydos (2000) defines performance as how well something does what it is supposed to do. In principle, two basic objectives of performance are accountability and improvement (Foster, 2001). Some of the performance dimensions are competitiveness, financialstability, quality of service, flexibility, resource utilisation and innovation (Nooreha, 2002).

Intellectual capital can be seen as the framework for intangible resources and also a way to understand these resources in an organisation. Intellectual capital comes as a leverage of knowledge management through an integrated approach to creating, share, and apply knowledge for desired outcomes and both intellectual capital and knowledge management are two branches of the same tree (Chatzkel, 2002). IC is transformed to economic value through organisational action (Madrid, 2004). IC enhances the environmental responsiveness of a firm thereby enhances the firmscompetitive advantage. The ability to manage knowledge for improving environmental responsiveness is associated with organisational learning (Khalique, Shaari and Md. Isa, 2011). Bontis, (2002) has it that IC is everything that cannot be touched but can earn money for the firm. Increased training of employees may lead to higher productivity and enhanced creativity. Managerial skills must be combined with relational and structural elements in theorganisation, to create value (Cabrita and Bontis, 2008).

Nielsen, Bukh, Mouritsen, Johansen and Gormsen (2006) argue that human capital, represented by the company's stock of, for example, skilled employees, knowledge and management philosophy helps to improve the company's growth. Managerial skills refer to the accumulated value of investments in employee training, competence, and future. The term focuses on the value of what the individual can produce; human capital thus encompasses individual value in an economic sense (Becker, 2002).

\subsection{Statement of the Problem}

In a developing country like Nigeria, intellectual capital is highly needed in virtually all business organisations for its effectiveness. It is hard for any business organisation to exist without adequate human and structural capital hence it is an indispensable tool for any business organisation. For employees to perform their functions effectively, there must be well-designed training and development programs to enable them enhance their productivity and pursue their career progression. These training and development programmes may range from on-the-job training scheme aimed at exposing employees to new techniques adopted in modern office environments. 
Most employers have reported inefficiency of some staff in business organisation in Nigeria, some of this inefficiency canbe attributed to their non-possession of the requisite skills, experiences and competencies. Also, the adverse effect of nepotism, godfatherism and favouritism during recruitment exercise has effects on career progression. The result is that such employees employed without due employment procedures find it extremely difficult to cope with the ever improving technological business environment. The problem of the study put in a question form is, what type of training, work experience, development should the female employees be exposed to enable them move with the demands of the ever-changing business world and at the same time be on top of their career?

\subsection{Objective of the Study}

The broad objective of the study focused on the effect of Intellectual Capital on Women Managers' Career Development in selected deposit money banks in South-East, Nigeria. The specific objectives sought to:

i. Ascertain the effect of proficiency on career management of women managers' in selected deposit money banks in South-East, Nigeria

\subsection{Research Question}

i. What is the effect of proficiency on career management of women managers' in selected deposit money banks in South-East, Nigeria?

\subsection{Research Hypothesis}

i. Proficiency does not significantly promote career management of women managers' in selected deposit money banks in South-East, Nigeria

\section{REVIEW OF RELATED LITERATURE}

\subsection{Conceptual Framework}

\subsubsection{Human Capital}

The concept of human capital relates to an individual's ability to allow for „changes in action" and economic growth through their knowledge and skills (Becker, 1962). It represents, in particular, the extraction of an individual employee's knowledge to get the best solutions for a firm (Bontis, Dragonetti, Jacobsen and Roos, 1999). Edvinsson and Malone (1997) define human capital as 'the collection of employees' skills, experience, competence and implicit knowledge". Dakhli and De Clercq (2004) identify it as one of the core constituents of intellectual capital. Dess and Shaw (2001) define "future human capital" as business people who are talented, smart and sophisticated; technologically savvy; internationally intelligent; operationally quick and well-coordinated. Human capital may also be defined from the social perspective as the intrinsic abilities, knowledge and skills accumulated in an individual's lifetime (Laroche and Merette, 1997).

\subsubsection{Human Capital and Women's Entrepreneurship}

In her ground-breaking article on female entrepreneurship, Schwartz (1976) found that there were very few differences in the personal qualities of male and female entrepreneurs. Later research by Hisrich and $\mathrm{O}^{\text {ec }}$ Brien $(1981,1982)$ confirmed this finding. Notwithstanding this similarity, it was found that female entrepreneurs find it difficult to overcome society's negative beliefs about women. There is a generally held perception that women do not have the right human capital to lead high-growth start-ups. Brush et al. (2004) argue that this perception is based on two primary assumptions: women lack the right education and sufficient or appropriate professional experience. 


\subsubsection{Human Capital and the Growth of Women-Owned Enterprises}

Women generally possess lower levels of human capital than men, including lower levels of education and reduced skill sets (Yetim, 2008). In addition, the type of human capital possessed is not gender neutral: men generally have higher levels of previous industrial or business related experience, including management of employees (Carter and Brush, 2005; Carter and Williams, 2003; Boden and Nucci, 2002; Jamali, 2009). This lack of human capital may affect women's ability to spot and exploit opportunities (Jamali, 2009), ultimately leading to reduced growth (Coleman, 2000).

However, the precise effects of human capital on the growth of women-owned enterprises are not totally clear cut. University-level education is not always a predictor of entrepreneurial activity and growth of women enterprises. In Taiwan, for example, highly educated women tend to join the professions, while less educated women start enterprises (Sanyang and Huang, 2008), with most entrepreneurial women being educated to an intermediate-level. However, Taiwanese women considered that business-specific skills such as internet and IT, management, sales, marketing, bookkeeping and accountancy were crucial for business success, and they made taking courses in these subjects a priority (Sanyang and Huang, 2008).

Coleman (2007) analyses data from the US Federal Reserve's 1998 Survey of Small Business Finances. The survey includes information on 3,561 small US firms (defined as firms having 500 or fewer employees). It was found that unwillingness to apply for loans (which is more common in women entrepreneurs) negatively affected profitability, indicating that a lack of confidence, which is a particular problem for women, can negatively affect growth. Prior business experience was a better indicator of profitability for women than for men, indicating that this form of human capital is particularly important in the growth of women-owned enterprises (Coleman, 2007). Surprisingly, previous business experience actually had a negative effect on growth for both male and female business owners. Coleman (2007) suggests that this may be because experienced owners are more aware of the risks of high growth and choose to grow their business more slowly, focusing on other performance measures. Coleman (2007) also found gender differences in the effects of human capital on growth. For women, none of the following human capital variables were significantly related to growth: level of education, age, prior experience, whether the business was family-owned, sole proprietorship, and whether the business was inherited. Financial capital variables such as the ability to secure loans were also not related to growth of women-owned enterprises. Coleman (2007) suggests the growth of female-owned businesses is related to other unmeasured factors, unconnected to human or financial capital Industry-specific experience is important for the growth of small businesses (Loscocco, Robinson, Hall, and Allen., 1991). This puts women at a disadvantage as they generally have fewer years of industry experience (Coleman, 2007), which makes it harder to seek out and take advantage of resources. Bruhn et al. (2010) investigate how managerial capital affects business growth for Peruvian women. In this randomized controlled study female micro-entrepreneurs were given lessons in business and recordkeeping skills. No improvement in revenue, profit or employment levels was shown in comparison to the control group.

\subsubsection{Relational Capital}

The relational capital is recognized as the relationships with customers, suppliers and stakeholders that influence the company's life. Cheng et al (2010) argues that customer relations are a crucial factor in competitive advantage which result an increase of corporate performance. Prahalad and Ramaswamy (2000) found that the customers are the source to 
increase the competency of organizations. Increase of organizational competency is based on customer's relations.

Relation capital includes all resources that are linked to the external relationships of the firm with customers, suppliers or other stakeholders. Therefore, relational capital is the knowledge that is included in the relationships with any stakeholder that affects the firm's life. Capello and Faggian (2005) assume that relational capital is a combination of different kind of relationships like market relationships, power relationships and cooperation. Chen et al (2006) assert that relational capital incorporate strong levels of understanding, trust, relationship and collaboration among strategic alliance partners, and therefore includes 'stocks of connections, interactions, linkages, closeness, goodwill and loyalty between a firm and its upstream suppliers, downstream clients, strategic partners or external stakeholders'. Guthrie and Petty (2000) describe it as 'external capital', which includes brands, customers and customer satisfaction, company names, distribution channels, business collaborations or licensing agreements. A loyal and sufficiently large customer base is vital to achieving economic success (Aaker, 1991; Keller, 1993; Fornell et al, 1996). In addition, Moon and Kym (2006) included community capital, which refers to the trust relationships, cooperation and collective action between stakeholders (Kogut and Zander, 1996; Nahapiet and Ghoshal, 1998). Elements of relation capital are mentioned below: Customer relationship, Customer loyalty and satisfaction, Distribution relationships and agreements, Relationships with other partners and other stakeholders, etc.

\subsection{Theoretical Framework}

\subsubsection{Resource-based theory}

Resource-based theory emphasizes the critical importance of internal resources for sustainable competitive advantage. This perspective argues that firm performance is a function of how well managers build their organizations around resources that are valuable, rare, inimitable, and lack substitutes (Barney, 1991). Intangible resources like human capital are more likely to produce a competitive advantage because they are rare and socially complex, and therefore difficult to imitate (Hatch and Dyer, 2004; Hitt et al., 2001). In particular, specific human capital represents an inimitable asset in terms of knowledge and skills that are only of use to an individual company (Lepak and Snell, 2002; Rauch et al., 2005). Networks are fundamental in structural capital because networks can provide resources, which may facilitate investment, can provide access to information, and reduce transactional cost. Trust is one of the resources that may be the result of networks (Zhang and Fung, 2006) and this is a resource that is socially complex and difficult to imitate. Firms obtain sustainable competitive advantages by implementing strategies that exploit their internal strengths, while neutralizing external threats and avoiding internal weaknesses. Strategic resources are heterogeneous and immobile across firms, and that these resources are stable over time.

The theory identifies the firm's potential key resources and evaluates whether these resources fulfill the following criteria:

Valuable - A resource must enable a firm to employ a value-creating strategy, by either outperforming its competitors or reduce its own weaknesses; Rare- To be of value, a resource must be rare by definition. In a perfectly competitive strategic factor market for a resource, the price of the resource will be a reflection of the expected discounted future above-average returns; In-imitable - If a valuable resource is controlled by only one firm it could be a source of a competitive advantage. This advantage could be sustainable if competitors are not able to duplicate this strategic asset perfectly. An important underlying factor of inimitability is causal ambiguity, which occurs if the source from which a firm's 
competitive advantage stems is unknown (Peteraf, 1993). If the resource in question is knowledge-based or socially complex, causal ambiguity is more likely to occur as these types of resources are more likely to be idiosyncratic to the firm in which it resides (Mahoney and Pandian, 1992). Non-substitutable - Even if are source is rare, potentially value-creating and imperfectly imitable, an equally important aspect is lack of substitutability. If competitors are able to counter the firm's value creating strategy with a substitute, prices are driven down to the point that the price equals the discounted future rents, resulting in zero economic profits.

\subsection{Empirical Review}

Mercy, Peter and: Martin (2015) conducted a study on Human Capital and Performance of Commercial Banks and Insurance Firms in Kenya .The purpose of the study was to establish the influence of human capital on the performance of insurance firms and commercial banks in Kenya. The study adopted a descriptive crosssectional survey design and a census survey was carried out on all the 43 licensed commercial banks and 45 insurance firms in Kenya. The target respondents were the Human Resources Managers and the questionnaire was the data collection instrument that was used. Out of the 88 firms that were targeted, 54 responded, constituting a response rate of $61 \%$. Hypothesis was tested using simple linear regression analysis. Descriptive statistics were computed for organizational data and the main characteristics of the study variables. Data was presented in form of tables. The findings revealed that the influence of human capital on non-financial measures of firm performance was statistically significant. These results are consistent with existing literature which points out a positive effect of human capital on firm performance. This study contributes to understanding the link between human capital and firm performance, while at the same time confirms the findings of previous studies that have found a significant link between human capital and firm performance. The study concluded that firm's human capital is an important source of sustained competitive advantage. The study recommended that Organizations can enhance their human capital by embracing rigorous selection procedures and matching the right people with the right jobs. Academic qualifications and work experience should be considered during selection.

Neelam, Israr and Shahid (2014) conducted a study on Impact of Training and Development on Employees Performance and Productivity .The main objective was to investigate whether training and development has impact on employees' performance and productivity. This paper is quantitative in nature. Data for the paper have been collected through primary source that are from questionnaires surveys. The data have been checked through statistical software to find the impact of training and development on employees' performance and productivity. There were two variable Training and Development (Independent) and Employees' performance and productivity (Dependant). Eight united banks limited were selected for the study. Eighty questionnaires were distributed for the collection of data. Descriptive statistic tools SPSS were applied on the questionnaire to see the reliability and consistency. The goal was to see whether Training and Development has an impact on Employees Performance and Productivity. Data were analyzed and discussed. The result showed that there was significant relationship between the variables, the Pearson correlation was used in study and Cronbach Alpha for each questionnaire was obtained. Frequency distribution was used to see the individual result of the study. The study recommended that organization should uphold to reduce deficiencies in their organisation.

\section{METHODOLOGY}

This study adopted a survey research design. The population of this study comprised of women Managers of 10 selected deposit money banks in Southeast, Nigeria. With a 
population of 4,624 women managers representing the banks from which samples of women top managers and middle manager were selected. A sample size was determined using BillGoddonwhichamount to531 while the response validity was obtained by re-contacting individuals whose responses appeared unusual or inconsistent. Validity of the instrument was done by giving it to management expert from the selected banks and three (3) academia that modified the instrument and made the necessary corrections so that the instruments measure what it ought to measure. The hypotheses were tested using Pearson product moment correlation coefficient and simple linear regression statistical tools. To ascertain that the instrument was reliable, test-re-test method was adopted in which 50 copies of the questionnaire were distributed to the banks understudy; five (5) copies to each bank in Enugu. These were collected afterwards and re-distributed after two weeks for the second time. The outcome of the test-re-test was determined using the Cronbach Alpha, the result gave a reliability coefficient of $r=0.762$.

\section{DATA PRESENTATION AND ANALYSIS}

\subsection{Presentation of Data}

Table 4.1 Presents the Response rate of Questionnaire Distributed to the staff of Commercial Banks in South East Nigeria

\begin{tabular}{|l|l|l|l|l|l|l|}
\hline Staff & $\begin{array}{l}\text { Copies of } \\
\text { Questionnaire } \\
\text { Distributed }\end{array}$ & $\boldsymbol{\%}$ & $\begin{array}{l}\text { Copies of } \\
\text { Questionnaire } \\
\text { Returned }\end{array}$ & \% & $\begin{array}{l}\text { Copies of } \\
\text { Questionnaire } \\
\text { not returned }\end{array}$ & $\%$ \\
\hline Senior & 52 & 10 & 40 & 8 & 12 & 2 \\
\hline Junior & 479 & 90 & 469 & 88 & 10 & 2 \\
\hline Total & $\mathbf{5 3 1}$ & $\mathbf{1 0 0}$ & $\mathbf{5 0 9}$ & $\mathbf{9 6}$ & $\mathbf{2 2}$ & $\mathbf{4}$ \\
\hline
\end{tabular}

\section{Source: Field Survey, 2016}

From table 4:1 it was revealed that five hundred and thirty one copies of questionnaire were distributed to the staff of deposit money banks in South east Nigeria (senior and junior staff). Five hundred and nine (96\%) copies of the questionnaire were filled and returned, twenty two $40(8 \%)$ was from senior staff while $469(88 \%)$ was from junior staff. However twenty two copies of the questionnaire were not returned, twelve $12(2 \%)$ was from senior staff while ten $10(2 \%)$ was from junior staff.

Objective one: To ascertain the effect of proficiency on career management in Nigeria deposit money banks

Table 4.2: Reponses as to Employees level of competency assistswomen managers in designing of career path

\begin{tabular}{|l|l|l|l|l|}
\hline Staff & Senior staff & Junior staff & Total & Percentage \\
\hline Strongly agree & 29 & 360 & 389 & 76 \\
\hline Agree & 6 & 90 & 96 & 19 \\
\hline Undecided & 2 & 3 & 5 & 1 \\
\hline Disagree & 2 & 8 & 10 & 2 \\
\hline Strongly disagree & 1 & 8 & 9 & 2 \\
\hline Total & $\mathbf{4 0}$ & $\mathbf{4 6 9}$ & $\mathbf{5 0 9}$ & $\mathbf{1 0 0}$ \\
\hline
\end{tabular}

\section{Source: Field Survey, 2016}

The tables 4.2 present the responses from staff based on questions related to objective one of this study. From table 4.2, it was revealed that three hundred and eighty nine (389) respondents representing $76 \%$ of staff strongly agreed that employees level of competency assistswomen managers in designing their career path. A break down indicates that twenty nine (29) of the respondents were senior staff of deposit money banks, three hundred and 
sixty (360) were junior staff of deposit money banks, ninety six (96) respondents representing $19 \%$ of staff agreed that employees level of competency assistswomen managers in designing their career path. A break down indicates that six (6) of the respondents were senior staff of the deposit money banks, Five (5) respondents $1 \%$ of staff were undecided that employees level of competency assistedwomen managers in designing their career path. A break down indicates that $\operatorname{two}(2)$ of the respondents were senior staff of deposit money banks and three(3) of the respondents were junior staff of deposit money bank in south east Nigeria.

Ten (10) respondents representing $2 \%$ of staff disagreed that employees level of competency assistedwomen managers in designing their career path. Two respondents were senior staff of deposit money banks in south east Nigeria and eight (8) respondents were junior staff of deposit money banks in south east. nine (9) respondents representing $2 \%$ of staff strongly disagreed that employees level of competency assisted womenmanagers in designing of career path A break down indicates that one (1) of the respondents was a senior staff of deposit money banks in south east Nigeria and eight (8) of the respondents were junior staff of deposit money bank in south east Nigeria.

\section{Test of Hypotheses}

\section{Hypothesis One}

Ho: Proficiency does not significantly promote career management in deposit money banks in South-East, Nigeria

Hi: Proficiency significantly promotes career management in deposit money banks in SouthEast, Nigeria

Table 4.3 Model Summary ${ }^{b}$

\begin{tabular}{|l|r|r|r|r|r|}
\hline Model & \multicolumn{1}{|c|}{$\mathrm{R}$} & $\mathrm{R}$ Square & $\begin{array}{c}\text { Adjusted R } \\
\text { Square }\end{array}$ & $\begin{array}{c}\text { Std. Error of the } \\
\text { Estimate }\end{array}$ & Durbin-Watson \\
\hline 1 & $.763^{\mathrm{a}}$ & .414 & .413 & .79669 & .070 \\
\hline
\end{tabular}

a. Predictors: (Constant), Proficiency

b. Dependent Variable: career management

Table 4.4ANOVA ${ }^{b}$

\begin{tabular}{|c|c|c|c|c|c|c|}
\hline \multicolumn{2}{|c|}{ Model } & $\begin{array}{l}\text { Sum of } \\
\text { Squares }\end{array}$ & df & Mean Square & $\mathrm{F}$ & Sig. \\
\hline 1 & Regression & 696.619 & 1 & 96.619 & 152.224 & $.000^{\mathrm{a}}$ \\
\hline & Residual & 654.174 & 507 & .635 & & \\
\hline & Total & 1350.793 & 508 & & & \\
\hline
\end{tabular}

a. Predictors: (Constant), Proficiency

Table 4.5Coefficients ${ }^{\mathrm{a}}$

\begin{tabular}{|ll|r|r|r|r|r|}
\hline \multirow{2}{*}{ Model } & \multicolumn{2}{|c|}{$\begin{array}{c}\text { Unstandardized } \\
\text { Coefficients }\end{array}$} & \multicolumn{2}{c|}{$\begin{array}{c}\text { Standardized } \\
\text { Coefficients }\end{array}$} & & \\
\cline { 2 - 5 } & \multicolumn{1}{|c|}{ B } & Std. Error & Beta & \multicolumn{1}{c|}{$\mathrm{t}$} & \multicolumn{1}{c|}{ Sig. } \\
\hline 1 & (Constant) & 1.119 & .055 & & 20.400 & .000 \\
& Proficiency & .307 & .025 & .763 & 12.338 & .000 \\
\hline
\end{tabular}

a. Dependent Variable: career management. 


$\begin{array}{ll}\mathrm{R} & =0.763 \\ \mathrm{R}^{2} & =0.414 \\ \mathrm{~F} & =152.224 \\ \mathrm{~T} & =12.338 \\ \mathrm{DW} & =.070\end{array}$

\section{Interpretation:}

The regression sum of squares (996.619) is greater than the residual sum of squares (654.174), which indicates that more of the variation in the dependent variable is not explained by the model. The significance value of the F statistics $(0.000)$ is less than 0.05 , which means that the variation explained by the model is due to chance.

Proficiency significantly promotes career management in Deposit money banks in SouthEast, Nigeria

$\mathrm{R}$, the correlation coefficient which has a value of 0.763 , indicates that proficiency significantly promotes career management in Deposit money banks in South-East, Nigeria. $\mathrm{R}$ square, the coefficient of determination, shows that $41.4 \%$ of the variation in career management is explained by the model.

With the linear regression model, the error of estimate is low, with a value of about .79669 . The Durbin Watson statistics of 0.070 , which is less than 2, indicates there is no autocorrelation.

The proficiency coefficient of 0.763 indicates that proficiency significantly promotes career management in Deposit money banks in South-East, Nigeria, which is statistically significant (with $\mathrm{t}=12.338$ ). Therefore, the null hypothesis should be accepted and the alternative hypothesis accordingly rejected. Thus Proficiency significantly promotes career management in deposit money banks in South-East, Nigeria

\subsection{Discussion of Result}

Hypothesis one was tested with simple linear regression to ascertain the effect of proficiency on career management in selected Deposit money banks in South-East, Nigeria. The result shows that proficiency significantly promotes career management in Deposit money banks in South-East, Nigeria $(\mathrm{r}=0.763 ; \mathrm{t}=12.338 ; \mathrm{F}=152.224 ; \mathrm{P}<0.05)$. O'Connel (2004) conducted a study on effect of competency on career management and the result indicates that competency significantly affects career management. Based on the result from the interview growth $65 \%$ of the respondents supported that educational qualification enhances proficiency for the promotion of women employees to managerial position which is inline with the findings of the study. Ome (2004) supported the result stating that proficiency significantly influences productivity in an organization.

\subsection{Summary of Findings}

i. Proficiency significantly promoted career developement of women managers in selected deposit money banks in South-East, Nigeria $(\mathrm{r}=0.763 ; \mathrm{t}=12.338 ; \mathrm{F}=$ $152.224 ; \mathrm{P}<0.05)$

\section{2: Conclusion}

The study concluded that intellectual capital is the key to achieving sustainable competitive advantage and drives economic growth. Intellectual capital, which is considered the most important intangible asset in the company, significantly affects the valuable change and 
success of the organization through understanding, developing and managing the company's intangible assets.

The survival and performance sustainability of an organization in the long run will be determined by how the right capital mix between physical and intellectual capital of the organization is leveraged to satisfy the interest of its stakeholders - shareholders, creditors, suppliers, customers, communities, employees including the whole human race, present and future and the planet itself. Intellectual capital which includes of human capital, structural capital and relational capital will play a central role in fueling the success of companies in this century.

\subsection{Recommendations}

Based on the findings, the following recommendations were made:

Organizations should constantly send their women managers on training/developmental programmes in order to reduce their deficiency that will turn out to increase organizational productivity.

\section{References}

1. Aaker, D.A. (1991). Managing Brand Equity, Now York: The Free Press.

2. Arenas, T. and Lavanderos, L. (2008). Intellectual Capital: Object or Process? Journal of Intellectual Capital, 9(1), 77-85.

3. Bontis, N. and Fitz-enz, J. (2002), "Intellectual Capital ROI: a Causal Map of Human Capital Antecedents and Consequents", Journal of Intellectual Capital, 3(3) 223-47

4. Bontis, N., Dragonetti, N. C., Jacobsen, K. and Roos, G. (1999). The Knowledge Toolbox: A Review of the Tools Available to Measure and Manage Intangible Resources". European Management Journal, 17 (4), 391-402

5. Cabrita, M. and Bontis N. (2008). "Intellectual Capital and Business Performance in the Portuguese Banking Industry", International Journal of Technology Management, 43, $1 / 2 / 3,212-237$

6. Capello R. and Faggian A. (2005). Collective learning and relational proximity in local innovation processes. Regional Studies, 39(1), pp. 75-87

7. Carrell, J. (2007). Intellectual Capital: An Inquiry into its Acceptance, Business Renaissance Quarterly? 2(1), 67-96.

8. Carroll, R.F. and Tansey, R.R. 2000. Intellectual capital in the new Internet economy - its meaning, measurement and management for enhancing quality. Journal of Intellectual Capital, 1(4), 296-312.

9. Carson, E., Ranzijn, R., Winefield, A., and Marsden, H. (2004). Intellectual Capital: Mapping Employee and Work Group Attitudes. Journal of Intellectual Capital, 5,(3) 443463.

10. Carson, E., Ranzijn, R., Winefield, A., and Marsden, H. (2004). Intellectual Capital: Mapping Employee and Work Group Attitudes. Journal of Intellectual Capital, 5, (3),443-463.

11. Carson, E., Ranzjin, R., Winefield, A. and Marsden, H. (2004). Intellectual capital: managing employee and work group attributes. Journal of Intellectual Capital, 5(3), pp. 443-456.

12. Chatzkel J. (2002). Intellectual Capital. London: Capstone Publishing

13. Chen, Y.S., Lin, M.J. and Chang, C.H. (2006). The influence of intellectual capital on new product development performance: The manufacturing companies of Taiwan as an example. Total Quality Management, 17 (10), pp. 1323-1339. 
14. Cheng M.Y., Lin J.Y., Hsiao T.Y. and Lin T.W. (2010). Invested resource, competitive intellectual capital, and corporate performance. Journal of Intellectual Capital, 11(4), 433450

15. Chin, Chen M., S. Ju Cheng and Y. Hwang,( 2005). An Empirical Investigation of the Relationship between Intellectual Capital and Firms Market Value" Journal of Intellectual the Relation between the Variables of the Research. Capital, 6(2): 159-176,

16. Edvinsson, L. (1997). Developing intellectual capital in Scandia. Long Range Planning, 30(3), pp. 320-331

17. Edvinsson, L. and Malone, M. S. (1997). Intellectual Capital: Realizing Your Company's True Value by Finding Its Hidden Brainpower. New York, NY: Harper Business

18. Fornell, C., Johnson, M.D., Anderson, E.W., Cha, J. and Bryant, B.E. (1996). The Americancustomer satisfaction index; nature, purpose and findings. Journal of Marketing, 60(1), pp. 7-18.

19. Guthrie, J., R. Petty, \& F. Ricceri. (2006). The voluntary reporting of intellectual capital. Comparing evidence from Hong Kong and Australia. Journal of Intellectual Capital, 7(2), pp. 25

20. Harrison, R(1990). Training and Development. New York: Institute of Personnel Management, 3(7), 7-14

21. Hitt, M.A., Bierman, L., Shimizu, K. and Kochhar, R. (2001). Direct and Moderating effects of Human Capital on Strategy and Performance in Professional Service Firms: a Resource-based Perspective, Academy of Management Journal, 44 (1), 13-28.

22. Johannessen, J., Olsen, B., and Olsen, J. (2005). Intellectual Capital as a Holistic Management Philosophy: a Theoretical Perspective. International Journal of Information Management, 25, 151-171.

23. Johanson, U. Martensson, M. and Skoog, M. (2001).Mobilising Change through the Management Control of Intangibles: Accounting, Organizations and Society Journal, 26 (7) 13-733.

24. Kaydos D.A. . (1998). The Strategic Management of Intellectual Capital. United States: Butterworth-Heinemann.

25. Kogut, B. and Zander, U (1992). Knowledge of the Firm, Combinative Capabilities, and the Replication of Technology. Organization Science 3, 383-397

26. Kogut, B. and Zander, U. (1996). What firms do? Coordination, identity and learning. Organization Science, 7 (5), pp. 502-519.

27. Laroche, M. and Merette, M. (1997) Measuring Human Capital. Canada: Department of Finance

28. Lepak, D.P. and Snell, S.A. (1999). The Human Resource Architecture: toward a Theory of Human Capital Allocation and Development, Academy of Management Review, 24, 3148

29. Mahoney, J.T. and Pandian, J.R. (1992). The Resource-Based View Within the Conversation of Strategic Management, Strategic Management Journal; 15 (5), 363-380.

30. Marr, B.(2004) "Management consulting practice on intellectual capital: Editorial and introduction to special issue", Journal of Intellectual Capital, 6, (4)496-473.

31. Mayo, F.D. (2000). "An Integrative Model of Organizational Trust", Academy of Management Review, 20 (3) 709- 34.

32. Mercy G and Peter K' (2015) Human Capital, Employee Empowerment and Performance of Commercial Banks and Insurance Firms in Kenya, International Journal of Arts and Commerce 4(6)9

33. Neelam, T., Israr K. and.Shahid,.S(2014) conducted a study on Impact of Training and Development on Employees Performance and Productivity, International Journal of Academic Research in Business and Social Sciences 4 (4) 13 
34. Neergaard, H., T., Nielsen, K. and Kjeldsen, J. I. (2006). State of the Art of Women's Entrepreneurship: Access to Financing and Financing Strategies in Denmark. In: Brush, C. G., Networks. San Fransisco: Berrett-Koehler Publishers.

35. Nielsen, C., Bukh, P., Mouritsen, J., Johansen, M. and Gormsen, P. (2006). Intellectual Capital Statements on their Way to the Stock Exchange", Journal of Intellectual Capital, 7 (2), 221-40.

36. Nonaka I. and Takeuchi H. (1995). The Knowledge Creating Company. New York: Oxford University Press

37. Nooreha I. (2000). Prophet Muhammad's Leadership. The Paragon of Excellence Altruistic Management. A Cross-application to Modern Management Leadership Practice. Kuala Lumpur: Utusan Publications \& Distributors Sdn. Bhd

38. Parker, S. C. and Van Praag, C. M. (2006). The Entrepreneur's Mode of Entry: Business Takeover or New Venture Start? Max Planck Institute of Economics: Entrepreneurship, Growth and Public Policy Group.

39. Peteraf, M.A. (1993). The Cornerstones of Competitive Advantage: A Resource-Based View. Strategic Management Journal; 14, (3) 179-191

40. Prahalad, C.K. and Ramaswamy, V. 2000. Co-opting customer competence. Harvard Business Review, 78(1), 79-87.

41. Rastogi, P. N. (2000), Sustaining Enterprise Competitiveness - Is Human Capital the Answer? Human Systems Management, 19 (3) 193-203

42. Sherman, W. H., Muñoz, A. J., and Pankake, A. (2008)."The Great Divide: Women's Experiences with Mentoring . Journal of Women in Educational Leadership, 6 (2), 239259

43. Stewart TA. (1997). Intellectual Capital: The New Wealth of Organizations. Currency Doubleday: New York.

44. Stewart, T. (1 997), Intellectual Capital: The New Wealth of Nations: Doubleday. 